\title{
DNA -M ediated Sensitive Detection and Quantification of Rare Earth Ions Using Polymerase Chain Reaction
}

\author{
K en Y okawa ${ }^{1}$, Takashi Kadono ${ }^{1,2}$, Y usuke Suzuki ${ }^{1}$, \\ Takuya Suzuki ${ }^{1}, K^{2}$ azuya U ezu and Tomonori Kawano1,* \\ IF aculty and Graduate School of Environmental Engineering, \\ The University of K itakyushu, K itakyushu, 808-0135, Japan \\ 2Fukuoka Industry, Science and Technology Foundation, Kitakyushu, 808-0135, J apan
}

(Received October 1, 2010; accepted November 16, 2010)

Key words biosensing, DNA, lanthanum PCR, rare earth, real-time PCR

In this article, a novel approach to a highly sensitive and quantitative detection of rare earth ions by the polymerase chain reaction (PCR) technique is described, by focusing on the catalytic activities of rare earth ions towards deoxyribonucleic acid (DNA). The detection of rare earth ions is based on the observation that rare earth ions such as $\mathrm{La}^{3+}$ act against PCR-dependent amplification of DNA. In addition to the detection of rare earth ions by the conventional PCR protocol with agarose gel elecrophoresis, we also quantified rare earth ions by real-time PCR. Finally, our approach using PCR greatly lowered the limit for the biochemical detection of rare earth ions at the ppb level.

\section{Introduction}

Our group has been engaged in studies of the biological sensing of various metal ions, chi efly trivalent cations of rare earth el ements, using living cells of plants, ${ }^{(1-3)}$ microbes, ${ }^{(4)}$ and protozoa. ${ }^{(5)}$ Plant cells responded to the trivalent cation of al uminum similarly to that of rare earth elements. ${ }^{(6-8)}$ In addition to living cells, some in vitro systems consisting of biological components such as metal-binding peptides were employed for the detection of rare earth ions. ${ }^{(9)}$ The target metal ions used in our previous approaches include $\mathrm{Na}$, $\mathrm{Mg}, \mathrm{Al}, \mathrm{K}, \mathrm{Ca}, \mathrm{Sc}, \mathrm{Mn}, \mathrm{Fe}, \mathrm{Co}, \mathrm{Ni}, \mathrm{Cu}, \mathrm{Zn}, \mathrm{Ga}, \mathrm{Sr}, \mathrm{Y}, \mathrm{Ag}, \mathrm{Cd}$, and In. L anthanides such as $\mathrm{L} a, \mathrm{Ce}, \mathrm{Pr}, \mathrm{Nd}, \mathrm{Sm}, \mathrm{Eu}, \mathrm{Gd}, \mathrm{Tb}, \mathrm{Dy}, \mathrm{Ho}, \mathrm{Er}, \mathrm{Tm}, \mathrm{Yb}$, and $\mathrm{Lu}$ have also been our targets of interest. Through such continuous studies, we revealed that biological responses can be utilized as markers or sensors of metal cations. ${ }^{(10)}$ In most cases, the likely target molecules, to which rare earth ions bind, within the living cells are cation-permeable ion channels(3) or respiratory burst oxidase homologues (RBOH) known as NADPH oxidases embedded within the plasma membrane; ${ }^{(1,11)}$ thus, biological membranes can be considered as one of the most important sites of actions of rare earth ions. In addition,

*Corresponding author: e-mail: kawanotom@env.kitakyu-u.ac.jp 
other cell-free macromolecules, such as proteins (peptides) and nucleic acids, can be the putative targets of ion binding or interactions in order to develop reliable protocols for the detection of metal ions. The present article focuses on the development of novel protocols for the detection of metal ions in aqueous samples using deoxyribonucleic acid (DNA) as the sensing macromolecule.

Komiyama and his colleagues have shown that rare earth ions possess various biocatalytic activities. For example, $\mathrm{La}^{3+}, \mathrm{Pr}^{3+}$, and other rare earth ions catalyze the formation of 3'-5'-cyclic adenosine monophosphate (cAMP) from adenosine-5'triphosphate (ATP) under physiological conditions. ${ }^{(12)}$ Furthermore, in cooperation with other metals, rare earth ions efficiently and nonenzymatically hydrolyze the phosphoester linkages in nucleic acids, ${ }^{(13)}$ thus leading to the degradation of $\mathrm{DNA}^{(14)}$ and ribonucleic acid (RNA). ${ }^{(15,16)}$ Therefore, DNA may be used as a probe for the detection of rare earth ions, through the observation of rare-earth-ion-dependent DNA degradation. However, the reported range of rare earth ion concentrations required for detectable DNA breakdown after agarose electrophoresis is approximately on the $\mathrm{mM}$ order (over ca. $100 \mathrm{ppm}$ ) which is not high enough to be used as a rare-earth-ion-sensing protocol.

Here, we attempted a novel DNA-based detection of rare earth ions on the ppb order, by employing and modifying the conventional polymerase chain reaction (PCR). ${ }^{(17)}$

\section{Materials and M ethods}

\subsection{Incubation of DNA with rare earth elements}

Prior to PCR and/or electrophoresis on agarose gels, DNA dissolved in water or buffer (at various concentrations described in the result section) was incubated with various concentrations of rare earth ions (at $37^{\circ} \mathrm{C}$ for $1 \mathrm{~h}$, unless indicated otherwise). The final concentrations of rare earth ions used for incubation with DNA are referred to when discussing the concentrations of rare earth ions required for DNA degradation or PCR inhibition.

\subsection{Preparation and purification of template DNA sequence}

For model PCR-based DNA amplification, a DNA fragment of 501 base pairs (bp) derived from pBR322 was amplified by PCR (Fig. 1). The primers used were gctgtaggcataggcttggt (forward) and cgactcetgcattaggaagc (reverse). PCR was performed as described below, using pBR322 as the template DNA. The resultant 0.5 kilobase $(\mathrm{kb})$ amplicon (corresponding to the $501 \mathrm{bp}$ sequence between the 137th and 638th bases in pBR322) was purified following agarose gel electrophoresis (by excising the $0.5 \mathrm{~kb}$ band and extracting the DNA). Then, the obtained DNA solution was used as the template for further PCR.

\subsection{PCR conditions}

PCR was performed using TaKaRa Ex Taq ${ }^{\circledR}$ (TaKaRa Bio Inc., Otsu, Japan). A 10 $\mu \mathrm{L}$ mixture of $0.5 \mathrm{kbp}$ DNA and a rare earth element was amplified in a $50 \mu \mathrm{L}$ PCR mixture in accordance with the manufacturer's instructions. The two primers (forward, gctgtaggcataggcttggt; reverse, cgactcctgcattaggaagc) used for model PCR demonstration 


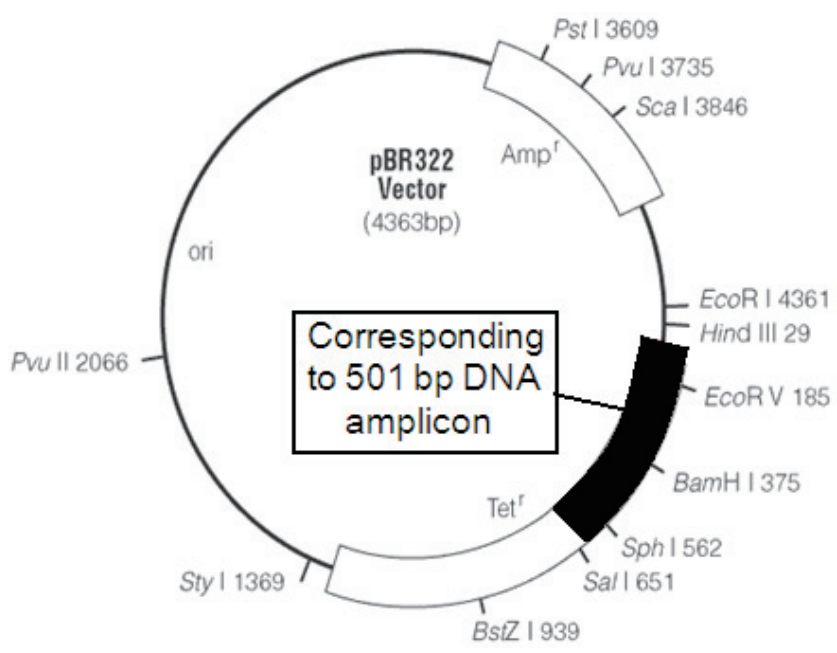

Fig. 1. Model DNA used for studying DNA-rare earth element interaction. From a commercially available plasmid pBR322, 501 bp (region between 137th and 638th bases) were amplified by PCR. The resultant amplicon was used as the template for further PCR. The map of pBR322 was obtained from the supplier's website (http://www.promega.com) and modified.

were identical to those used for preparing the template amplicon from pBR322. Thermal cycling conditions comprised an initial denaturation step at $94^{\circ} \mathrm{C}(2 \mathrm{~min})$, followed by 25 cycles of annealing at $94^{\circ} \mathrm{C}(1 \mathrm{~min}), 59.5^{\circ} \mathrm{C}(1 \mathrm{~min})$, and $72^{\circ} \mathrm{C}(1 \mathrm{~min})$, and then an additional extension at $72^{\circ} \mathrm{C}(10 \mathrm{~min})$ performed with the Program Temp Control System PC-320 (ASTEC, Fukuoka, Japan). Each PCR product was detected on 2\% agarose gel.

\subsection{Real-time PCR}

Real-time PCR was performed using $\mathrm{iQ}^{\mathrm{TM}} \mathrm{SYBR}^{\circledR}$ Green Supermix (Bio-Rad, CA). A $10 \mu \mathrm{L}$ mixture of $0.5 \mathrm{kbp}$ DNA and a rare earth element was amplified in a $25 \mu \mathrm{L}$ PCR mixture in accordance with the manufacturer's instructions. The specific primers used were the forward primer gctgtaggcataggettggt and the reverse primer cgactcctgcattaggaagc. Thermal cycling conditions comprised an initial denaturation step at $95^{\circ} \mathrm{C}(1 \mathrm{~min})$, followed by 25 cycles of annealing at $95^{\circ} \mathrm{C}(30 \mathrm{~s}), 59.5^{\circ} \mathrm{C}(30 \mathrm{~s})$, and $72^{\circ} \mathrm{C}(40 \mathrm{~s})$. Then, an additional extension at $72^{\circ} \mathrm{C}(5 \mathrm{~min})$ was performed with CHROMO4 (Bio-Rad, CA). The amplification of each PCR product was optically monitored using Opticon Monitor version 3.0 (Bio-Rad, CA).

\subsection{Rare earth samples}

For the preparation of rare earth samples, chloride salts $\left(\mathrm{LnCl}_{3}\right)$ were dissolved in water and diluted to the required concentrations. 


\subsection{Sampling and analysis of natural waters}

The water samples used as the sources of minerals (abundant ions possibly compete with rare earth ions) were a local tap water sample (Kitakyushu city tap water) and river water sample (Onga River, Fukuoka, Japan). For river water sampling, 5 different water catchments listed in limnological data base were selected. ${ }^{(18)}$ Within $12 \mathrm{~h}$ after sampling, a sample of approximately $10 \mathrm{~mL}$ was filtered with a cellulose acetate membrane filter (MILLIPORE, $0.22 \mu \mathrm{m}$ ) and kept at $5^{\circ} \mathrm{C}$ before measurement of ion concentrations. Ionic analyses were performed using an ion chromatograph (DX-120, Japan Dionex).

\section{Results and Discussion}

\subsection{Preliminary DNA degradation assay}

By simply incubating the DNA $(0.5 \mathrm{~kb}$ PCR amplicon from pBR322, at $150 \mu \mathrm{M})$ with rare earth samples $\left(\mathrm{LaCl}_{3}, \mathrm{TbCl}_{3}\right.$, and $\left.\mathrm{EuCl}_{3}\right)$ at $37^{\circ} \mathrm{C}$ for $1 \mathrm{~h}$, rare-earth-elementdependent degradation of DNA (bleaching of the corresponding band on agarose gel) was detectable, but only in the presence of high concentrations $(3-30 \mathrm{mM})$ of rare earth elements (data not shown).

\subsection{Inhibition of PCR-based DNA amplification by rare earth elements}

Although the bleaching of DNA by rare earth ions (DNA-degradation activity) is detectable only in the presence of high concentrations of rare earth elements (as confirmed above), we expected that the bleaching of small amounts of DNA could be induced by a low concentration of rare earth ions. Therefore, we attempted to detect the interaction between DNA and rare earth elements at low concentrations after DNA amplification by PCR.

Figure 2 shows the results of DNA amplification (template DNA concentration, 150 $\mathrm{pM}$ ) in the presence of $\mathrm{La}^{3+}, \mathrm{Eu}^{3+}, \mathrm{Y}^{3+}$, and $\mathrm{Tb}^{3+}$ in the $\mu \mathrm{M}$ and sub- $\mu \mathrm{M}$ ranges. The concentrations of DNA and rare earth ions shown here correspond to the concentrations used in the template DNA degradation reaction at $37^{\circ} \mathrm{C}$ for $1 \mathrm{~h}$. Compared with the positive control (with template DNA but without rare earth ions) showing the band corresponding to the $0.5 \mathrm{bp}$ DNA amplicon on agarose gel, samples with rare earth ions showed inhibition of DNA amplification, possibly due to rare-earth-ion-catalyzed complete or partial degradation of template DNA. In the case of La addition, the inhibition of PCR was detectable in the presencce of $1 \mu \mathrm{M} \mathrm{La}$ (ca. $139 \mathrm{ppb}$ ), and the band was no longer detectable in the presence of $10 \mu \mathrm{M}$ La (Fig. 2(a)). Y and Eu completely inhibited PCR at 30 and $100 \mu \mathrm{M}$, respectively (Figs. 2(b) and 2(c)). Tb also showed a partial inhibitory effect at $100 \mu \mathrm{M}$ (Fig. 2(d)).

The reproducibility of PCR inhibition by La under the above standard condition was examined by repeating the experimental process 8 times (Fig. 3). The concentration of $\mathrm{La}$ ions required for the complete inhibition of PCR was $4.75 \mu \mathrm{M}$ (S.D, $0.43 \mu \mathrm{M})$. Since the reproducibility of the lanthanum-dependent inhibition of PCR was confirmed by conventional PCR, we concluded that a PCR-mediated protocol is applicable to the detection and quantification of low concentrations of lanthanum. 


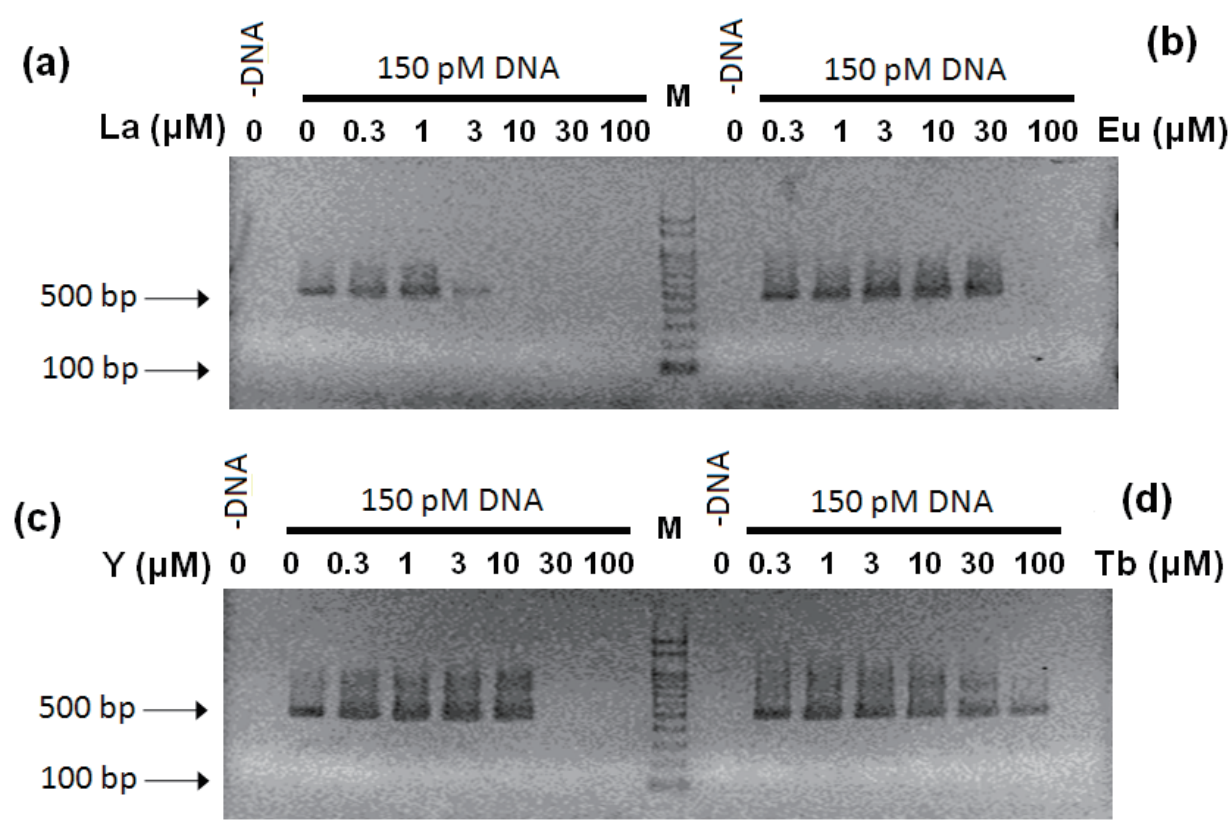

$M$ : size marker

Fig. 2. Inhibition of PCR by rare earth elements. Template DNA (0.5 kb DNA derived from pBR322) at $150 \mathrm{pM}$ was incubated with rare earth ions $(0,0.3,1,3,10,30$, and $100 \mu \mathrm{M})$ and subjected to PCR and agarose gel electrophoresis. Effects of $\mathrm{La}(\mathrm{a}), \mathrm{Eu}(\mathrm{b}), \mathrm{Y}(\mathrm{c})$, and $\mathrm{Tb}(\mathrm{d})$ were compared.

\subsection{La-dependent inhibition of PCR tested under various water conditions}

For developing a reliable protocol for the detection of trace levels of rare earth ions in the environment, the effects of competing cations such as $\mathrm{Na}^{+}, \mathrm{K}^{+}, \mathrm{Mg}^{2+}$, and $\mathrm{Ca}^{2+}$ and anions such as $\mathrm{Cl}^{-}$and $\mathrm{SO}_{4}^{-}$, which are abundant in natural water environments, must be examined. Therefore, we tested the effect of various water samples from the natural water environment as the solvent for La ions and DNA. Following the incubation of DNA and La ions in different water samples, PCR and agarose gel electrophoresis were performed (Fig. 4). The water samples used were, ultrapure water, local tap water (Kitakyushu city water), and river water samples (Onga River, Fukuoka, Japan). According to the limnological database documented by our group ${ }^{(18)}$ river water samples can be categorized as upstream water (river water sample A), midstream water (river water samples B and C), and downstream water (river water samples D and E). The ionic composition of the water samples used are listed in Table 1. Among the samples, mineral contents were lower in river water samples A and B. The mineral compositions in the tap water sample were similar to those in the downstream water samples. In general, the contents of cations $\left(\mathrm{Na}^{+}+\mathrm{K}^{+}+\mathrm{Mg}^{2+}+\mathrm{Ca}^{2+}\right)$ in these samples are ca. 320- to 490-fold higher at molar ratio and ca. 64- to 81-fold higher at weight ratio, than that of 
(a)
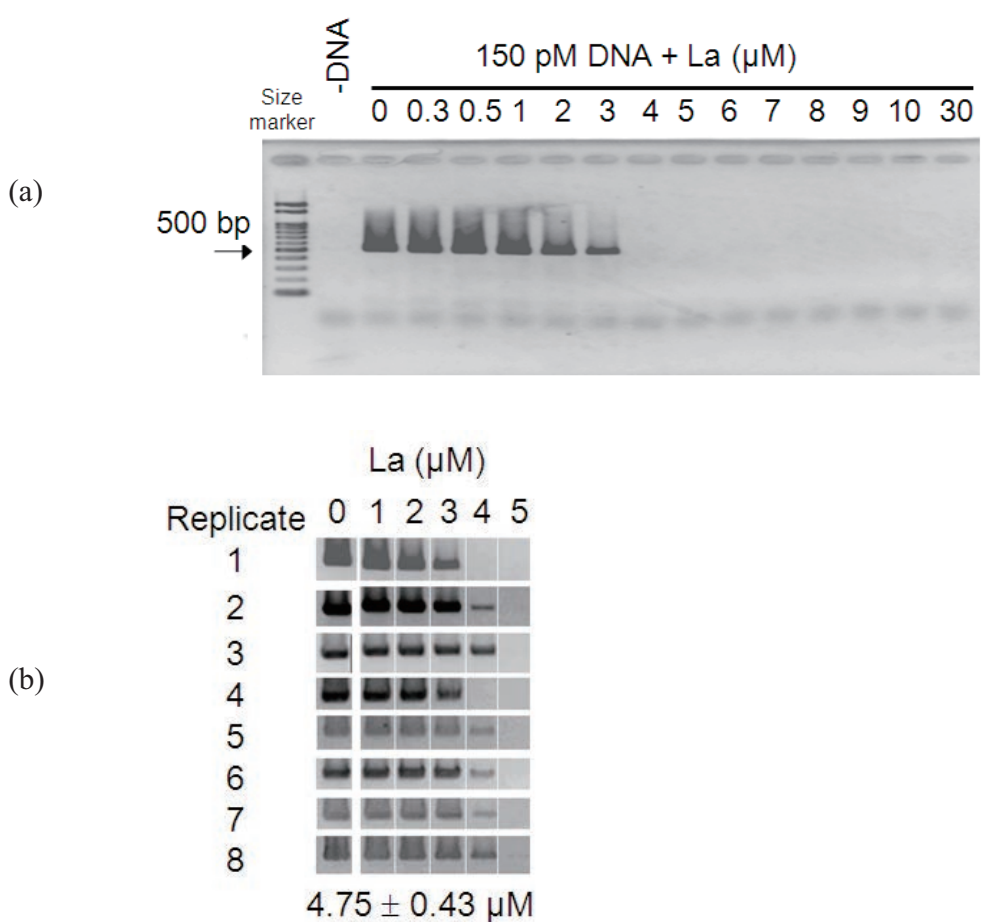

Fig. 3. Inhibition of PCR by lanthanum. Template DNA (0.5 kb DNA derived from pBR322) at $150 \mathrm{pM}$ was incubated with La ions $(0,1,2,3,4$, and $5 \mu \mathrm{M})$ and subjected to PCR and agarose gel electrophoresis. (a) Typical result showing La-dependent inhibition of amplicon production by PCR in concentration-dependent manner. (b) Replication of La-dependent inhibition. The mean concentration of La required for complete inhibition of PCR was determined to be $4.75 \mu \mathrm{M}$ (S.D. $=0.43$ $\mu \mathrm{M} ; \mathrm{n}=8)$.

La ions tested. Figure 4 shows that the inhibitory effect of La ions on PCR is insensitive to ions present in natural water samples. This suggests that our newly developed protocol is applicable to the detection of rare earth ions in the natural environment water samples containing abundant competing ions.

Although the above data suggest that the PCR-mediated rare earth ion detection protocol is highly specific to rare earth ions (compared with the ions of alkaline metals and alkali rare earth metals), the specificity of the detection protocol for each of the 16 rare earth elements is low at this moment. Therefore, we need to develop some additional preparation protocols to enhance the resolution or specificity for rare earth elements.

\subsection{Quantification of lanthanum using real-time (quantitative) PCR}

For the ease of the quantification of lanthanum, we used real-time PCR, which allows the kinetic analysis of DNA amplification by optically monitoring the increase in 


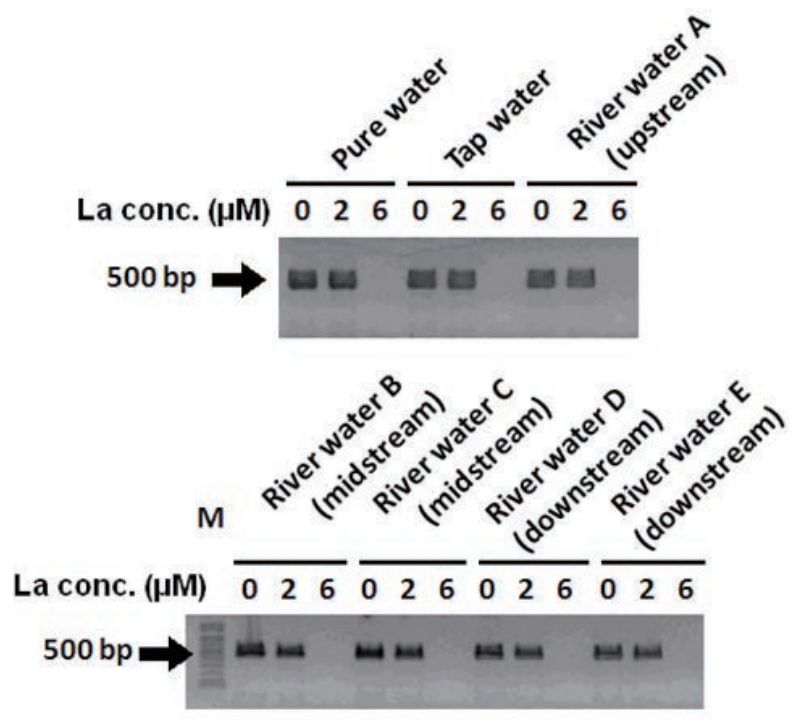

Fig. 4. Lanthanum-dependent inhibition of PCR performed for various water samples. Template DNA (0.5 kb DNA derived from pBR322) at $150 \mathrm{pM}$ was incubated with La ions $(0,2$, and $6 \mu \mathrm{M})$ in pure water or various water samples obtained from tap water or rivers, prior to PCR and agarose gel electrophoresis. Chemical (ionic) compositions of water samples used are listed in Table 1.

Table 1

Mineral compositions of water samples used for dissolving La ions.

\begin{tabular}{lrrrrrr}
\hline \multirow{2}{*}{ Water samples } & \multicolumn{5}{c}{ Mineral content (mg/L) } \\
\cline { 2 - 7 } & $\mathrm{Na}^{+}$ & \multicolumn{1}{c}{$\mathrm{K}^{+}$} & $\mathrm{Mg}^{2+}$ & $\mathrm{Ca}^{2+}$ & $\mathrm{Cl}^{-}$ & $\mathrm{SO}_{4}^{-}$ \\
\hline Pure water & N.D. & N.D. & N.D. & N.D. & N.D. & N.D. \\
Tap water (Kitakyushu City) & 28.63 & 1.78 & 3.95 & 18.67 & 18.13 & 35.77 \\
River water A (upstream) & 8.12 & 0.96 & 1.74 & 6.47 & 4.34 & 4.77 \\
River water B (midstream) & 13.67 & 2.15 & 2.91 & 12.78 & 8.11 & 15.00 \\
River water C (midstream) & 58.40 & 2.11 & 4.48 & 24.33 & 16.77 & 55.75 \\
River water D (downstream) & 35.32 & 2.99 & 4.35 & 24.90 & 17.48 & 45.57 \\
River water E (downstream) & 29.44 & 2.90 & 3.68 & 22.01 & 13.92 & 35.90 \\
\hline
\end{tabular}

The river water samples were from Onga River, Kyushu, Japan. N.D., not detectable

the concentration of the fluorescent probe (intercalator)-labeled double-stranded DNA amplicon (Fig. 5).

Although the linear relationship between fluorescence intensity and the concentration of La ions at the end point ( 38 cycles) was nominally detectable (data not shown), the yield of fluorescence and La concentrations showed a high linearity at 12, 14, and 16 cycles of PCR (Fig. 5). This indicates that automated quantification might be possible if the real-time PCR protocol was optimally modified, which remains as a future task. 
(a)

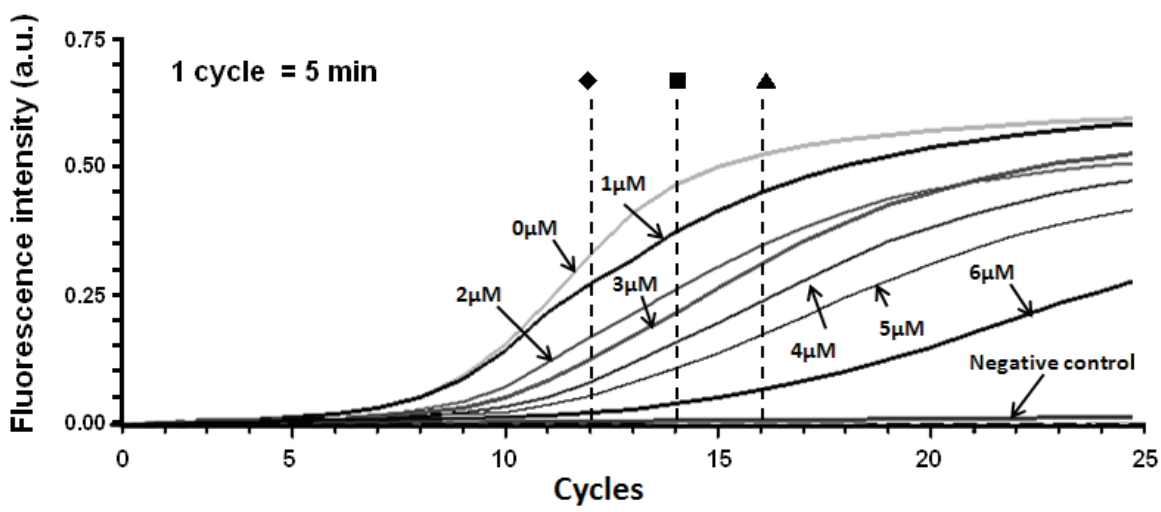

(b)

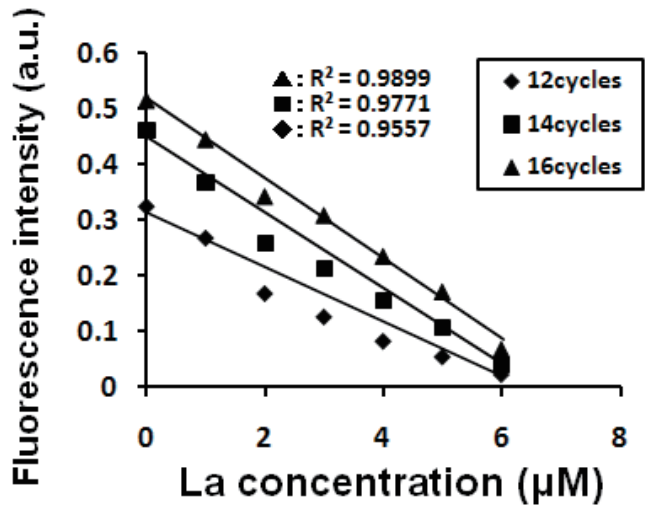

Fig. 5. Detection and quantification of lanthanide ions by real-time (quantitative) PCR. (a) Temporal profile of DNA amplification and its inhibition in the presence of various concentrations of $L a$ ions. (b) Relationship between $L a$ ion concentration and inhibition of PCR (dose-dependent decrease in DNA fluorescence intensity) analyzed at 12th, 14th, and 16th cycles of PCR .

\subsection{Biphasic melting profiles of PCR amplicons}

When performing the thermal melting profile analysis of end-products of real-time PCR (Fig. 6(a)), a La concentration-dependent decrease in the amount of the major amplicon and the emergence of a novel amplicon with a low-temperature melting profile (suggesting the presence of smaller fragments of DNA) were observed. Although the mechanism behind this phenomenon is unknown at present, the emergence of such unexpected amplicon(s) may be one of the key characteristics of the rare-earth-iondependent inhibition of PCR.

Interestingly, the emergence of unusual small amplicons was also observed on agarose gel. Figure 6(b) shows the cases of PCR demonstration with $T b$ and $\mathrm{Eu}$. These data suggest that the novel fragments favor very narrow ranges of rare earth ion concentrations (thus they are not suitable for quantification, but help in the characterization of the lanthanide-dependent chemistry). 
(a)

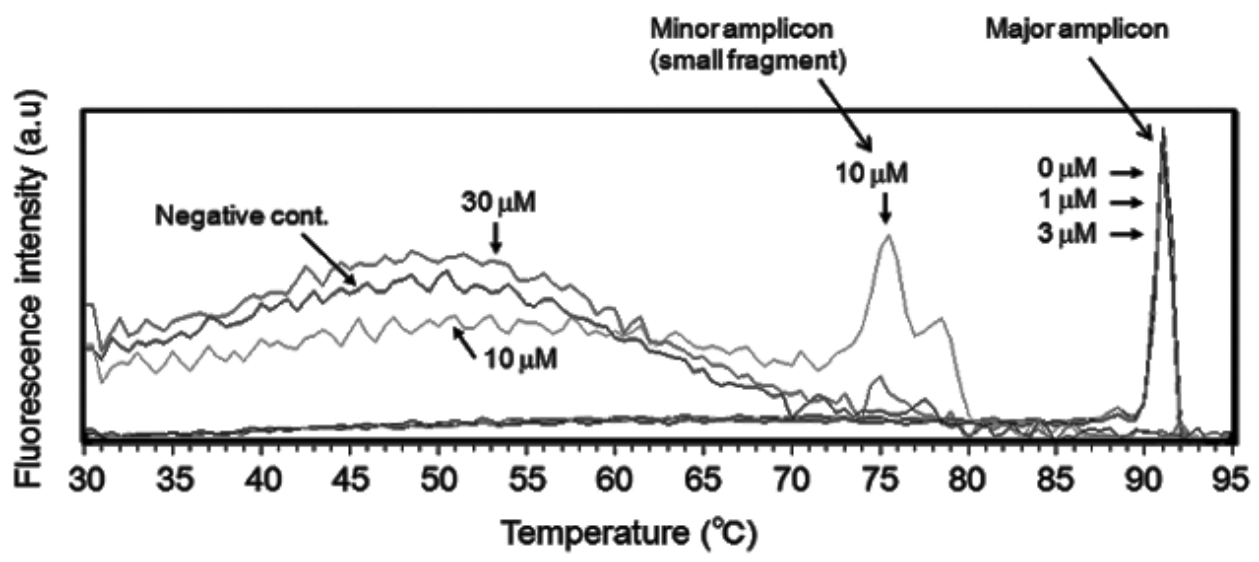

(b)

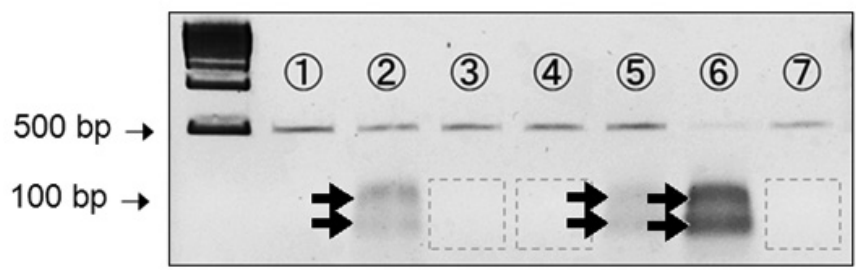

Fig. 6. Emergence of additional amplicons. (a) The melting profiles for DNA amplicons assessed with real-time PCR (melting profiles of DNA amplicons produced in the presence and absence of La ions). Two different amplicons with different melting profiles were determined. At a higher concentration of $\mathrm{La}$ ions $(10 \mu \mathrm{M})$, the original amplicon found in the control was no longer detectable. Instead, an additional low-temperature-melting amplicon was found. (b) Emergence of secondary bands in the presence of rare earth elements in narrow concentration range. Lanes (1) $15 \mathrm{pM}$ DNA only, (2) DNA +0.3 nM Tb, (3) DNA +3 nM Tb, (4) DNA +30 nM Tb, (5) DNA +0.3 $\mathrm{nM} \mathrm{Eu},(6) \mathrm{DNA}+3 \mathrm{nM} \mathrm{Eu}$, (7) DNA +30 nM Eu.

\section{Conclusion}

Our novel approach of employing PCR greatly lowered the limit for the biochemical detection of a variety of rare earth ions (enables detection of rare earth ions at the ppb level). Usually, to detect such trace concentrations of metals with high sensitivity, highly complex analytical instruments such as an inductively coupled plasma (ICP)-mass spectrometer are required; therefore, the initial cost of detecting such trace chemicals is very high. In contrast, the cost performance of our protocol is outstanding since the instrument required for our novel protocol for detecting rare earth ions is merely a thermal cycler (PCR machine). In addition, the quantification of rate earth ions present in aqueous solution by real-time PCR was demonstrated. The development of automated protocols for quantitative analyses of lanthanides with high sensitivity is highly encouraged for future study. 


\section{Acknowledgement}

This work was supported by a grant from the K nowledge Cluster Initiative implemented by the Ministry of Education, Culture, Sports, Science and Technology (MEXT), J apan.

\section{R eferences}

1 T. Kawano, N. Kawano, S. M uto and F. Lapeyrie: Plant Cell Environ. 24 (2001) 1235.

2 T. Kawano, N. Kawano, S. M uto and F. Lapeyrie: Physiol. Plantarum 114 (2002) 395.

3 C. Lin, T. Kadono, K. Y oshizuka, T. Furuichi and T. K awano: Z. Naturforsch. 61c (2006) 74.

4 R. Pinontoan, S. Krystofava, T. Kawano, I. C. M ori, F. Tsuji, H. Iida and S. Muto: Biosci. Biotechnol. Biochem. 66 (2002) 839.

5 M. A onuma, T. Kadono and T. Kawano: Z. Naturforsch. 62c (2007) 93.

6 T. Kawano, T. Kadono, T. Furuichi, S. Muto and F. Lapeyrie: Biochem. Biophys. Res. Commun. 308 (2003) 35.

7 T. Kawano, T. Kadono, K. Fumoto, F. Lapeyrie, M. K use, M. I sobe, T. Furuichi and S. M uto: Biochem. Biophys. Res. Commun. 324 (2004) 40.

8 C. Lin, Y. Y u, T. Kadono, M. I wata, K. U memura, F. Furuichi, M. Kuse, M. Isobe, Y. Y amamoto, M. M astumoto, K. Y oshizuka and T. K awano: Biochem. Biophys. Res. Commun. 332 (2005) 823.

9 T. Kawano: ITE Lett. 7 (2006) 383.

10 T. Kawano: ITE Lett. 4 (2003) 44.

11 T. Kawano, T. Kadono, S. C. Y ang and S. M uto: Noncompetitive inhibition of lanthanideinduced oxidative burst by zinc in tobacco BY-2 cells: A chemiluminescent analysis in Bioluminescence and Chemiluminescence Progress and Perspectives, eds. A. Tsuji, M. M atsumoto, M. M aeda, L. J. K ricka, P. E. Stanley (W orld Sci. Publ. Co. Pte. Ltd., Singapore, 2005) p. 299.

12 H. Y ajima, J. Sumaoka, S. M iyama and M. K omiyama: J. Biochem. 115 (1994) 1038.

13 M. Irisawa and M. Komiyama: J. B iochem. 117 (1995) 465.

14 M. K omiyama: J. Biochem. 118 (1995) 665.

15 M. Y ashiro, A. I shikubo and M. Komiyama: J. B iochem. 120 (1996) 1067.

16 K. M atsumura and M. K omiyama: J. Biochem. 122 (1997) 387.

17 K. B. Mullis and F. A . Faloona: M ethods Enzymol. 155 (1987) 335.

18 S. Nishihama, A. Haraguchi, T. Kawano, K. M ichiki, K. Nakazawa, T. Suzuki, K. U ezu and K. Y oshizuka: Limnology 9 (2008) 35. 